\title{
PERLINDUNGAN HUKUM TERHADAP DOKTER DALAM PEMBUKAAN REKAM MEDIK PASIEN HUMAN IMMUNODEFICIENCY VIRUS/ACQUIRED IMMUNODEFICIENCY SYNDROME Oleh: Siti Handayani ${ }^{1}$
}

\begin{abstract}
This research aims to 1) to describe, identify and analyze the authority of physicians in the patient's medical record opening of HIV/AIDS, and 2) to analyze and solve the problem of legal protection for doctors in the open medical record on HIV/AIDS patients.

This research use approach to legislation. Data research results obtained from the interview with the Director of the PROVINCIAL HOSPITAL Majenang, HIV/AIDS Counselors and doctors responsible poly HIV/AIDS HOSPITALS Majenang. Data research results are analyzed using deductive methods.

Based on the results of research and discussion as follows: first, the authority of the doctor in the patient's medical record opens HIV/AIDS organized in Permenkes RI number 269/MENKES/PER/III/2008 and 36 year 2012 number of Secret Medicine that is only for the interests of the patient's health, meet the demand for law enforcement apparatus in order on the order of a Court of law enforcement that must be requested in writing to the Chairman of the House means health services. Request or consent of the patients themselves, request the institution/institutions on the basis of the provisions of the legislation as well as for the purposes of research, education and medical audit all not mentioning the identity of the patient, as well as a condition threaten the safety of others individually and in society. The individual in question is potentially the most transmission of HIV/AIDS that is wife or husband HIV/AIDS sufferers. Second, the legal protection in the open medical record on HIV/AIDS patients are given by the Government in the prevention aims to prevent the occurrence of the dispute, which directs the action being taken by the existence of a variety of conditions regulated in the law practice of medicine, health and the regulation of the Minister of health. Protection legal protection in repressive if violation occurs already in the practice of medical service aimed at handling a particular dispute which are also regulated in the PENAL CODE and regulations peundang-invitation to assure doctors and patients get the rights and obligations in accordance with the provisions of the applicable legislation. Keywords: legal protection, HIV/AIDS
\end{abstract}

\section{ABSTRAK}

Penelitian ini bertujuan 1) untuk mendeskripsikan, mengidentifikasi dan menganalisis kewenangan dokter dalam membuka rekam medik pasien HIV/AIDS, dan 2) untuk menganalisis dan memecahkan masalah perlindungan hukum bagi dokter dalam membuka rekam medis pada pasien HIV/AIDS.

Penelitian ini menggunakan pendekatan perundang-undangan. Data hasil penelitian diperoleh dari wawancara dengan Direktur RSUD Majenang, Konselor HIV/AIDS dan dokter penanggungjawab poli HIV/AIDS RSUD Majenang. Data hasil penelitian dianalisis menggunakan metode deduktif.

Berdasarkan hasil penelitian dan pembahasan sebagai berikut: Pertama, kewenangan dokter dalam membuka rekam medik pasien HIV/AIDS diatur dalam Permenkes RI nomer 269/MENKES/PER/III/2008 dan nomer 36 tahun 2012 tentang Rahasia Kedokteran yaitu hanya untuk kepentingan kesehatan pasien, memenuhi permintaan aparatur penegak hukum dalam rangka penegakan hukum atas perintah

${ }^{1}$ Dokter Rumah Sakit Kabupaten Cilacap 
871 | J u rna I I d e a H u k u m

$\mathrm{Vol}, 4 \mathrm{No}, 1 \mathrm{Maret} 2018$

Magister Hu k u $\mathrm{FakuItas} H$ u k u $\mathrm{m}$ U n iversitas

J e ndera I Soedirman

pengadilan yang harus dimintakan secara tertulis kepada pimpinan sarana pelayanan kesehatan. Permintaan dan atau persetujuan pasien sendiri, permintaan institusi/lembaga berdasarkan ketentuan perundang-undangan serta untuk kepentingan penelitian, pendidikan dan audit medis sepanjang tidak menyebutkan identitas pasien, serta suatu kondisi yang mengancam keselamatan orang lain secara individu maupun masyarakat. Individu yang dimaksud adalah orang yang paling berpotensi tertularnya HIV/AIDS yaitu istri atau suami penderita HIV/AIDS. Kedua, perlindungan hukum dalam membuka rekam medis pada pasien HIV/AIDS diberikan oleh pemerintah secara preventif bertujuan untuk mencegah terjadinya sengketa, yang mengarahkan tindakan yang bersikap kehati-hatian dengan adanya berbagai ketentuan yang diatur dalam undang-undang praktik kedokteran, kesehatan dan peraturan menteri kesehatan. Perlindungan perlindungan hukum secara represif jika sudah terjadi pelanggaran dalam praktek pelayanan kedokteran yang bertujuan untuk penanganan suatu sengketa tertentu yang juga diatur dalam KUHP dan peraturan peundang-undangan untuk menjamin dokter dan pasien mendapatkan hak dan kewajibannya sesuai dengan ketentuan peraturan perundang-undangan yang berlaku.

Kata Kunci : Perlindungan hukum, HIV/AIDS

\section{A. Pendahuluan}

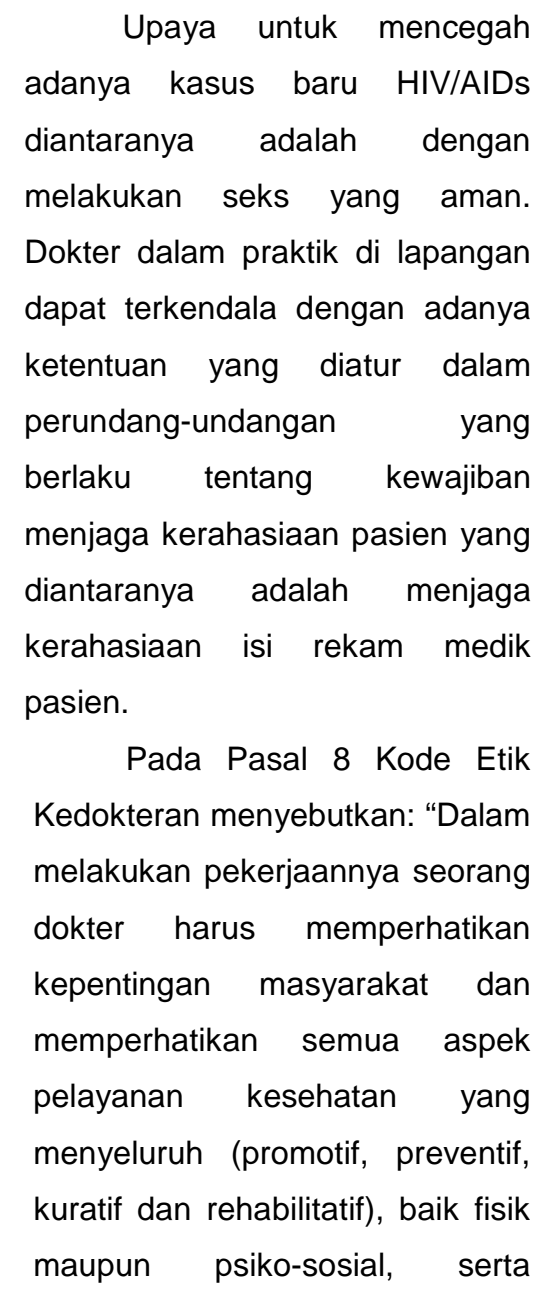

berusaha menjadi pendidik dan

pengabdi masyarakat yang

sebenar-benarnya".

Membuka rahasia pasien

HIV/AIDS berarti melanggar sumpah jabatan dan wajib simpan rahasia kedokteran. Sebagaimana diketahui, kewajiban utama dari profesional masyarakat ilmu kesehatan maupun tenaga kesehatan adalah melindungi hakhak pasien dengan menjaga kerahasiaan rekam medis pasien HIV/AIDS. Kaidah turunan moral bagi tenaga kesehatan adalah privacy (berarti menghormati hak privacy pasien), convidentiality (berarti kewajiban menyimpan informasi kesehatan sebagai rahasia), fidelity (berarti kesetiaan) dan veracity (berarti menjunjung tinggi kebenaran dan kejujuran). ${ }^{2}$

2 Samsi Jacobalis, 2005, Pengantar Tentang Perkembangan Ilmu 


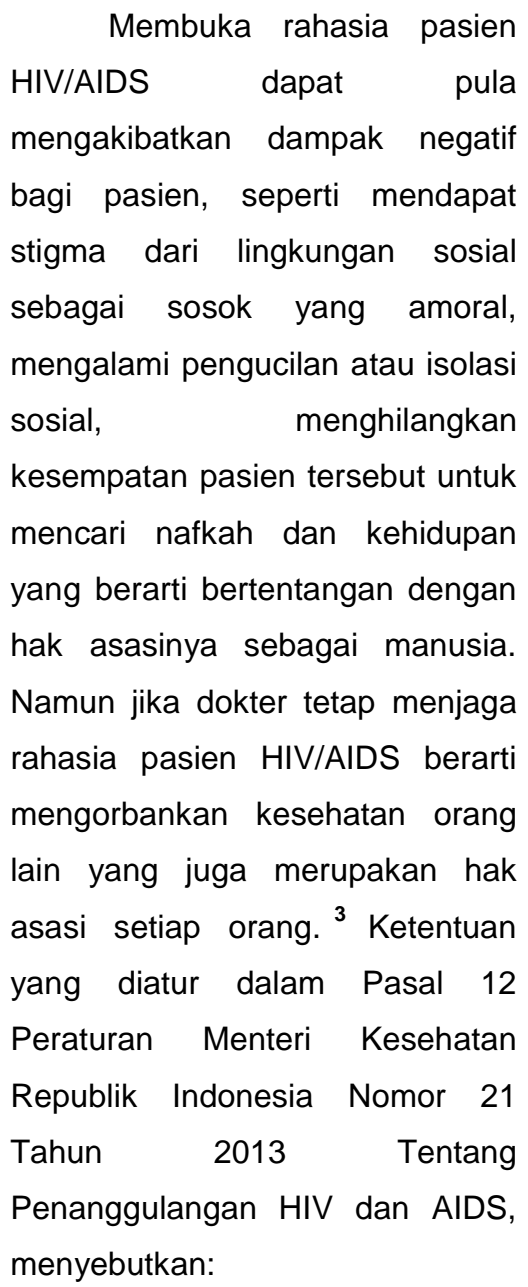

(1) Pencegahan penularan HIV dapat dicapai secara efektif dengan cara menerapkan pola hidup aman dan tidak berisiko.

Kedokteran, Etika Medis, dan Bioetika, CV Sagung Seto bekerjasama dengan Universitas Tarumanegara, Jakarta.

3 M. Taufik. 2011. "Perspektif Yuridis Tanggung Jawab Dokter Terhadap Rahasia Medis Pasien HIV/AIDS (Studi di Rumah Sakit Umum Daerah Banyumas)" Jurnal Dinamika Hukum Vol. 11 No. 3 September 2011.
(2) Pencegahan sebagaimana dimaksud pada ayat (1) meliputi upaya :

a. pencegahan penularan HIV melalui hubungan seksual;

b. pencegahan penularan HIV melalui hubungan non seksual; dan

c. pencegahan penularan HIV dari ibu ke anaknya;

Terkait dengan HIV/AIDS, prinsip yang dianut secara universal pada saat ini dan diadopsi oleh Pemerintah Indonesia bahwa pemeriksaan HIV/AIDS pada setiap orang dengan azas sukarela dan rahasia (Keputusan Menteri Koordinator Bidang Kesejahtaraan Rakyat No. 9//KEP/Menko/Kesra/VI/1994 tentang Strategi Nasional Penanggulangan HIV/AIDS di Indonesia), artinya tidak dapat diwajibkan karena bertentangan dengan HAM sehingga perlu ada informed consent terlebih dahulu baik pemeriksaannya maupun membuka untuk diberitahukan kepada orang lain. ${ }^{4}$ Sejalan

4 Margarita M. Maramis, 2007, Konseling dan Tes Sukarela Untuk Penderita HIV 
a I I d a H u k u m

Vol. $4 \mathrm{No}, 1 \mathrm{M}$ a re t 2018

Ma gister H u k m F a k I tas H u k u U n i versitas

Jenderal soedirman

$\begin{array}{rrr}\text { dengan itu, menurut Instruksi } & \\ \text { Menteri } & \text { Kesehatan }\end{array}$

72/MenKes/Inst/1988 tentang

Kewajiban Melaporkan Penderita

Dengan Gejala AIDS, tindakan

yang diambil petugas kesehatan

dan sarana pelayanan kesehatan

pada saat ditemuinya seseorang

dengan gejala AIDS hanyalah

pelaporan kepada Dirjen P2MPLP

(Pemberantasan Penyakit Menular

dan Penyehatan Lingkungan

Pemukiman) saja, dengan

memperhatikan kerahasiaan

pribadi pasien, sementara

lingkungan tidak diberitahu kalau

ada pasien penderita HIV/AIDS

dengan alasan HAM.

Dokter juga berkewajiban untuk menjaga dan melindungi hak orang lain untuk hidup sehat, setidaknya orang-orang yang terdekat dengan pasien. Oleh karenanya, dilema untuk tetap menyimpan rahasia kedokteran pasien HIV/AIDS adalah hal yang sangat sulit bagi dokter. Meskipun secara fisik dokter tidak mendapat tekanan, namun secara psikis dokter akan terbebani sepanjang hidupnya. ${ }^{5}$ Kondisi demikian menempatkan dokter dalam conflict of interest, yaitu di satu sisi harus menjaga rahasia pasien

\& AIDS, dalam Nasronudin \& Margarita M. Maramis (editor), Konseling, Dukungan, Perawatan \& Pengobatan $O D H A$, Airlangga University Press, Surabaya.

5 M. Taufik. 2011. Loc. Cit sesuai sumpah jabatan dan kode etik, namun di sisi lain harus menjaga serta melindungi hak orang lain untuk hidup sehat.

Menurut Satijipto Raharjo, perlindungan hukum adalah memberikan pengayoman terhadap hak asasi manusia (HAM) yang dirugikan oleh orang lain dan perlindungan itu diberikan kepada masyarakat agar dapat menikmati semua hak-hak yang diberikan oleh hukum. ${ }^{6}$ Menurut Philipus M. Hadjon bahwa perlindungan hukum bagi rakyat sebagai tindakan pemerintah yang bersifat preventif, dan represif. Perlindungan hukum preventif bertujuan untuk mencegah terjadinya sengketa, yang mengarahkan tindakan yeng bersikap kehati-hatian, sedangkan perlindungan represif bertujuan untuk penanganan suatu sengketa tertentu. ${ }^{7}$

Terkait dengan hal tersebut, maka pembukaan rekam medik oleh dokter pada pasien HIV/AIDS harus mendapatkan perlindungan hukum, karena dapat dijadikan upaya penting dalam penanggulangan HIV/AIDS,

6 Satijipto Raharjo, 2000. Ilmu Hukum. Bandung: PT. Citra Aditya Bakti, hlm. 53

7 Maria Alfons, 2010. Implementasi Perlindungan Indikasi Geografis atas Produk-Produk Masyarakat Lokal dalam Prespektif Hak Kekayaan Intelektual. Malang: Universitas Brawijaya. hlm. 18 
terutama terkait dengan penularan HIV/AIDS di keluarga maupun di masyarakat.

Penelitian ini bertujuan untuk mendeskripsikan, mengidentifikasi dan menganalisis kewenangan dokter dalam membuka rekam medik pasien HIV/AIDS dan untuk menganalisis dan memecahkan masalah perlindungan hukum bagi dokter dalam membuka rekam medis pada pasien HIV/AIDS.

\section{B. METODE PENELITIAN}

Penelitian ini merupakan penelitian perundang-undangan. Penelitian ini lebih bersifat deskriptif normatif, yaitu penelitian yang bertujuan untuk menggambarkan norma-norma tertulis yang dibuat dan diundangkan oleh pejabat yang berwenang dan memandang hukum sebagai suatu sistem normatif yang mandiri, bersifat tertutup dan terlepas dari kehidupan masyarakat nyata. ${ }^{8}$ Penelitian dilaksanakan di Program Pascasarjana ilmu Hukum Universitas Jenderal Soedirman dan RSUD Majenang. Jenis data yang digunakan yaitu data primer dan data sekunder. Data primer adalah data yang langsung diperoleh dari sumber pertamanya. ${ }^{9}$ Data primer

Ibid: hlm. 137-139.

Sumadi Suryabrata. 1992. Metode Penelitian. Rajawali Press. Jakarta. hlm. penelitian ini berupa hasil wawancara dengan nara sumber yang meliputi Direktur RSUD Majenang, Konselor HIV/AIDS dan dokter penanggungjawab poli HIV/AIDS RSUD Majenang. Data sekunder adalah data yang biasanya telah tersusun dalam bentuk dokumen-dokumen. ${ }^{10}$ Data sekunder dalam penelitian ini meliputi:

a. Bahan Hukum Primer : Yaitu berupa ketentuan perundang undangan, terdiri dari:

1) UUD 1945 Dan semua Konstitusi yang pernah berlaku di Indonesia

2) Undang-undang Nomor 29 Tahun 2004 tentang Praktik Kedokteran

3) Undang-undang Nomor 36 Tahun 2009 tentang Kesehatan

4) Peraturan Menteri Kesehatan Republik Indonesia Nomor 21 Tahun 2013 Tentang Penanggulangan HIV dan AIDS

5) Permenkes No. 269 Tahun 2008 tentang Rekam Medik

6) Kode Etik Kedokteran Indonesia

7) Permenkes No. 36 Tahun 2012 tentang Rahasia Kedokteran
84.

${ }^{10}$ Ibid. h. 85. 
875 | J u rna I I d e a H u k u m

$\mathrm{Vol}, 4 \mathrm{No}, 1 \mathrm{Maret} 2018$

Magister H u k u $\mathrm{F}$ a kultas H u k u $\mathrm{m}$ n i versitas

Jendera I Soedirman

b. Bahan Hukum Sekunder, yaitu terdiri dari bahan yang memberikan penjelasan mengenai bahan hukum primer, seperti buku-buku, tesis, surat kabar, artikel internet, hasil-hasil penelitian, pendapat para ahli atau sarjana hukum serta hasil yang dapat mendukung pemecahan masalah yang diteliti dalam penelitian ini.

Pengumpulan data primer menggunakan wawancara secara lisan dan tertulis menggunakan pedoman wawancara yang dilakukan terhadap Direktur RSUD Majenang, Konselor HIV/AIDS dan dokter penanggungjawab poli HIV/AIDS RSUD Majenang. Data yang telah terkumpul, selanjutnya dianalisa dengan menggunakan metode deduktif.

\section{HASIL PENELITIAN DAN PEMBAHASAN}

\section{Kewenangan Dokter Dalam Membuka Rekam Medik Pasien HIV/AIDS.}

Wewenang adalah pengertian yang berasal dari hukum organisasi pemerintahan, yaitu dapat dijelaskan sebagai keseluruhan aturan-aturan yang berkenaan dengan perolehan dan penggunaan wewenang-wewenang pemerintahan oleh subyek hukum publik di dalam hubungan hukum publik. ${ }^{11}$ Wewenang pemerintah dalam negara hukum berasal dari peraturan perundang-undangan yang berlaku, artinya sumber wewenang bagi pemerintah adalah peraturan perundang-undangan. Ridwan HR mengutip pendapat H.D. Van Wijk/Willem Konijnenbelt, menjelaskan secara teoritis kewenangan yang bersumber dari peraturan perundang-undangan dapat diperoleh melalui tiga cara, yaitu: ${ }^{12}$ Attributie: toekenning van een bestuursbevoegheid door een wetgver aan een bestuurusorgaan (atribusi adalah pemberian kewenangan pemerintahan oleh pembuat undang-undang kepada organ pemerintahan); Delegatie: overdracht vaan een behogheid van het een bestuursorgaan aan een ander (delegasi adalah pelimpahan wewenang pemerintahan dari satu organ pemerintahan kepada organ pemerintahan lainnya); dan Mandaat: een bestuursorgaan laat zijn bevogheid namens hem uitoefenen door een ander (mandat terjadi ketika organ pemerintahan mengijinkan kewenangannya dijalankan oleh organ lain atas namanya).

Kewenangan yang dimiliki dokter dalam penyelenggaraan praktik kedokteran harus dilaksanakan dengan penuh tanggungjawab yang dilakukan

11 Ridwan, HR, 2002, Hukum Administrasi Negara, UII Press, Yogyakarta, hlm. 65.

12 Ibid, hlm 75. 
sesuai dengan norma-norma hukum yang berlaku. Tanggung jawab hukum adalah suatu keseharusan bagi seseorang untuk melaksanakan apa yang telah diwajibkan kepadanya. S.J. Fochema Andrea menggunakan istilah verantwoordelijk yang berarti tanggung jawab dengan batasan sebagai berikut : aansprakelijk, verplicht tot het afleggen van verantwoording entot het dragen van event, toerekenbare schade (desgevorderrd), ini rechte of in bestuursverband (tanggung jawab adalah kewajiban untuk memikul pertanggungjawaban dan hingga memikul kerugian (bila dituntut atau jika dituntut) baik dalam kaitan dengan hukum maupun dalam administrasi). ${ }^{13}$

Profesi kedokteran adalah suatu pekerjaan kedokteran yang dilaksanakan berdasarkan suatu keilmuan, kompetensi yang diperoleh melalui pendidikan yang berjenjang, dan kode etik yang bersifat melayani masyarakat. Profesi adalah bidang pekerjaan yang dilandasi pendidikan keahlian (keterampilan, kejuruan, dan sebagainya) tertentu. ${ }^{14}$ Menurut Daldiyono, profesi adalah suatu bidang atau jenis pekerjaan yang

13 Az.Nasution. 2011. Hukum Perlindungan Konsumen Suatu Pengantar. Jakarta: Diadit Media. hlm. 48-49

14 Christine S.T. Kansil, 1997, PokokPokok Etika Profesi Hukum, Jakarta: Pradnya Paramita, hlm 3. memerlukan pendidikan khusus. Tidak semua jenis pekerjaan dapat disebut profesi karena suatu profesi memiliki ciri spesifik yaitu: ${ }^{15}$ ada bidang ilmu tertentu yang jelas dan tegas yang dipelajari, misalnya profesi kedokteran yang melaksanakan ilmu kedokteran, ada sejarahnya dan dapat diketahui pendahulunya, adanya suatu ikatan profesi yang bersifat independen dan berhak mengatur anggotanya, dan bersifat melayani dengan mementingkan yang dilayani (altruism) yang diatur dalam kode etik.

Dokter adalah orang yang menjalankan praktik-praktik pengobatan yang memegang wewenang menurut peraturanperaturan yang berlaku. ${ }^{16}$ Tindakan atau perbuatan dokter sebagai subjek hukum dalam pergaulan masyarakat, dapat dibedakan antara tindakannya sehari-hari yang tidak berkaitan dengan profesi dan tindakan yang berkaitan dengan pelaksanaan profesi. Begitu pula tanggung jawab hukum seorang dokter, dan dapat pula merupakan tanggungjawab hukum yang berkaitan dengan pelaksanaan profesinya. ${ }^{17}$

Perkembangan yang begitu

15 Daldiyono, 2007, Pasien Pintar dan Dokter Bijak, Jakarta: Buana Ilmu Popular, hlm 175.

16 Christine S.T. Kansil, 1991, Pengantar Hukum Kesehatan Indonesia, Jakarta: Rineka Cipta, hlm 2.

17 Ibid. hlm 2-3 
877 | J u rna I I d e a H u k u m

Vol, 4 No, $1 \mathrm{Maret} 2018$

Magister Hukum FakuItas Hukum Universitas

Jenderal Soedirman

pesat di bidang biologi dan ilmu kedokteran seiring dengan permasalahan di bidang kesehatan yang makin kompleks yang menuntut sejumlah etika dalam penyelenggaraan kedokteran. Etika kedokteran berbicara tentang bidang medis dan profesi kedokteran, terutama hubungan dokter dengan pasien, keluarga, masyarakat, dan teman sejawat. Oleh karena itu, sejak tiga dekade terakhir ini telah dikembangkan bioetika atau yang disebut juga dengan etika biomedis Prinsip-prinsip dasar etika adalah suatu aksioma yang mempermudah penalaran etik. Konsil Kedokteran Indonesia mengadopsi prinsip etika kedokteran barat menetapkan praktik kedokteran Indonesia mengacu pada 4 kaidah dasar moral yang disebut kaidah dasar etika kedokteran, yaitu beneficence, Nonmalficence, J ustice, Autonomy. Beneficence yaitu prinsip bahwa seorang dokter berbuat baik, menghormati martabat manusia. Dalam prinsip ini dikatakan bahwa perlunya perlakuan yang terbaik bagi pasien. Beneficence membawa arti menyediakan kemudahan dan kesenangan kepada pasien mengambil langkah positif untuk memaksimalisasi akibat baik dari pada hal yang buruk. Nonmalficence adalah suatu prinsip dimana seorang dokter tidak melakukan perbuatan yang memperburuk pasien dan memilih pengobatan yang terkecil risikonya bagi pasien. J ustice adalah suatu prinsip dimana seorang dokter memperlakukan sama rata dan adil untuk kebahagiaan dan kenyamanan pasien. Autonomy adalah prinsip bahwa seorang dokter menghormati martabat manusia. Setiap individu harus diperlakukan sebagai manusia yang mempunyai hak menentukan nasib diri sendiri. Dalam hal ini pasien diberi hak untuk berfikir secara logis dan membuat keputusan sendiri. Autonomy bermaksud menghendaki, menyetujui, membenarkan, membela, dan membiarkan pasien demi dirinya sendiri.

Pasien adalah orang sakit yang membutuhkan bantuan dokter untuk menyembuhkan penyakit yang dideritanya, pasien dapat diartikan juga adalah orang sakit yang awam mengenai penyakitnya. ${ }^{18}$ Menurut Pasal 1 ayat (10) UU Praktik Kedokteran, pasien adalah setiap orang yang melakukan konsultasi masalah kesehatannya untuk memperoleh pelayanan kesehatan yang diperlukan baik secara langsung maupun tidak langsung kepada dokter atau dokter gigi.

Rekam medis merupakan salah satu bukti tertulis tentang proses pelayanan yang diberikan oleh dokter dan dokter gigi. Setiap kegiatan pelayanan medis harus

18 Willa Candrawila. 2004, Hukum Kedokteran Mandar Maju: Bandung, hlm. 20 
mempunyai rekam medis yang lengkap dan akurat untuk setiap pasien dan setiap dokter dan dokter gigi wajib mengisi rekam medis dengan benar, lengkap dan tepat waktu. Tujuan rekam medis adalah untuk menunjang tercapainya tertib administrasi dalam rangka upaya peningkatan pelayanan kesehatan. Rekam medis berisi data-data administrasi pasien. ${ }^{19}$

Membuka rahasia pasien HIV/AIDS berarti melanggar sumpah jabatan dan wajib simpan rahasia kedokteran. Sebagaimana diketahui, kewajiban utama dari profesional masyarakat ilmu kesehatan maupun tenaga kesehatan adalah melindungi hak-hak pasien dengan menjaga kerahasiaan rekam medis pasien HIV/AIDS. Kaidah turunan moral bagi tenaga kesehatan adalah privacy (berarti menghormati hak privacy pasien), convidentiality (berarti kewajiban menyimpan informasi kesehatan sebagai rahasia), fidelity (berarti kesetiaan) dan veracity (berarti menjunjung tinggi kebenaran dan kejujuran). ${ }^{20}$

Membuka rahasia pasien HIV/AIDS dapat pula mengakibatkan dampak negatif bagi pasien, seperti mendapat stigma dari lingkungan sosial sebagai sosok yang amoral, mengalami pengucilan atau isolasi sosial, menghilangkan kesempatan

19 Nusye K.I Jayanti, 2009.Penyelesaian Hukum Dalam Malperaktek Kedokteran, Yogyakarta, Pustaka Yustisia, hlm. 85

20 Samsi Jacobalis, Loc. Cit. pasien tersebut untuk mencari nafkah dan kehidupan yang berarti bertentangan dengan hak asasinya sebagai manusia. Namun jika dokter tetap menjaga rahasia pasien HIV/AIDS berarti mengorbankan kesehatan orang lain yang juga merupakan hak asasi setiap orang. ${ }^{21}$

Menjaga kerahasiaan rekam medik pasien, khususnya pasien HIV/AIDS menjadi tanggungjawab dokter yang harus dilakukan tanpa mengurangi upaya yang dilakukan dokter dalam memberikan pelayanan kedokteran yang terbaik bagi pasien dan juga masyarakat. Tanggung jawab hukum dokter adalah suatu keterikatan dokter terhadap ketentuan-ketentuan hukum dalam menjalankan profesinya. Tanggung jawab seorang dokter dalam bidang hukum terbagi 3 (tiga) bagian, yaitu tanggung jawab hukum dokter dalam bidang hukum perdata, tanggung jawab pidana dan tanggung jawab hukum administrasi. ${ }^{22}$ Prinsip dasar pertanggungjawaban atas kesalahan mengandung arti bahwa seseorang harus bertanggungjawab karena ia telah bersalah karena melakukan sesuatu yang telah merugikan orang lain. Sebaliknya dengan prinsip tanggungjawab resiko adalah

21 M. Taufik. 2011. Loc. Cit.

22 Ninik Maryati, 1998, Malpraktik Kedokteran dari Segi Hukum Pidana dan Perdata,. Jakarta, Bina Aksara, hlm. 5 . 
sebagai dasar pertanggungjawaban, maka pasien penggugat tidak diwajibkan lagi membuktikan kesalahan dokter tergugat sebab menurut prinsip ini dasar pertanggungjawaban bukan lagi kesalahan melainkan dokter tergugat lansung bertanggungjawab sebagai resiko profesinya. ${ }^{23}$

Pasien HIV/AIDS pada prinsipnya sama dengan pasien lain yang menderita penyakit dan membutuhkan pertolongan medis dari tenaga kesehatan. Namun sifat penyakit HIV/AID yang menular dan berisiko besar terhadap kematian dan penyebabnya diantaranya terkait dengan perilaku seksual sehingga dalam penanggulangannya mendapatkan perhatian yang khusus. Penanggulangan HIV/AIDS melibatkan berbagai tenaga kesehatan yang ada diantaranya bertindak sebagai konselor.

Pelayanan kesehatan pasien HIV meliputi: ${ }^{24}$ Skrining, dalam hal ini konselor akan melakukan penyuluhan terhadap masyarakat dan tempat yang dicurigai HIV; Pasien penderita TB dianjurkan untuk periksa HIV; Pasien yang ada di bangsal yang dicurigai HIV akan dilakukan pemeriksaan HIV atas advis dokter bangsal; Penderita HIV

23 Triwulan Tutik, T. 2010. Perlindungan Hukum Bagi Pasien Jakarta,..Prestasi Pustaka. hlm.49

24 Informasi dari Dokter Penanggung Jawab Poli HIV akan mendapatkan konseling tentang pengetahuan HIV; Penderita HIV akan mendapatkan obat dan cara pemakaiannya serta mendapat pengawasan dalam minum obat HIV; Penderita HIV dimotivasi agar tidak menularkan kepada orang lain; Penderita HIV akan mendapatkan edukasi tentang bagaimana cara penularan HIV dan Long live HIV; Di RSUD Majenang mempunyai standar skrining HIV, bahwa setiap dilakukan operasi harus dilakukan cek HIV; Pasien HIV dikumpulkan dalam suatu komunitas bertujuan mempererat hubungan antar sesama pasien HIV yang akan memperkuat psikologis sesama penderita HIV.

Tenaga kesehatan yang bisa menjadi konselor HIV adalah semua tenaga kesehatan. Untuk saat ini yang tersedia di rumah sakit adalah dokter dan perawat. Tidak ada persyaratan khusus untuk menjadi konselor. Untuk menjadi konselor harus mengikuti pelatihan konseling HIV yang diadakan dinas kesehatan provinsi. Setelah mengikuti konseling maka petugas kesehatan akan mendapat sertifikat pelatihan konselor HIV. Konselor HIV merupakan tim yang ada diinstasnsi baik puskesmas atau rumah sakit. Konselor bertanggung jawab atas rahasia semua pasien HIV. Konselor hanya akan membuka rahasia pasien HIV apabila persetujuan pasien dengan menggunakan informed consent. Konselor HIV 
tidak boleh membocorkan rahasia

Rekam Medik pasien HIV baik kepada istri atau suami, keluarga dekat maupun masyarakat yang lain .Konselor HIV tidak akan membuka rahasia rekam medik pasien HIV walaupun atas permintaan masyarakat. $^{25}$

Kerahasiaan data Rekam Medik HIV dijaga oleh konselor dan dokter penanggung jawab HIV yang ada di bagian rekam medik. Apabila penderita HIV mau membuka rahasia tentang penyakit HIV ada 2 cara: ${ }^{26}$ disampaikan oleh penderita HIV sendiri, disampaikan oleh konselor atas seijin pasien HIV. Apabila penderita keberatan untuk dibuka data rekam mediknya maka konselor HIV tidak boleh membuka rekam medik pasien HIV tersebut, kecuali untuk kepentingan pengadilan atau untuk keilmuan, tetapi tidak menyebutkan identitas HIV.

Data pasien HIV diketahui oleh konselor penanggung jawab poli HIV, serta penanggung jawab rekam medik HIV. Direktur Rumah Sakit, kabid dan kasi pelayanan di rumah sakit tidak mengetahui rekam medik pasien HIV, konselor hanya melaporkan penderita HIV kepada Kepala Bidang Pelayanan, melaporkan kepada Dinas Kesehatan Kabupaten Cilacap tentang jumlah HIV tanpa

25 Informasi dari Konselor HIV AIDS. 26 Ibid. menyebutkan identas pasien HIV. ${ }^{27}$

Tim konselor yang bertanggung jawab tentang data rahasia rekam medik HIV terdiri dari dokter, perawat, penanggung jawab poli HIV, dokter yang mengobati pasien di RSUD Majenang. Seluruhnya wajib merahasiakan data rekam medik pasien HIV. Apabila pada pasien rawat inap yang terdapat pasien HIV maka penyampaian informasi tersebut dilakukan oleh konselor dengan cara hati hati dan tertutup. Dengan dilakukan konseling oleh konselor apabila pasien membolehkan data tersebut diketahui orang lain. Prosedur standart operasional dengan inform concent. ${ }^{28}$ Yang berhak diberikan data rekam medik pasien HIV adalah: ${ }^{29}$ Pasien, orang lain/keluarga atas seijin pasien dengan tanda tangan pada informed concent, untuk kepentingan keilmuan tanpa menyebutkan identitas pasien, untuk kepentingan pengadilan.

Standar operasional pelayanan HIV di RSUD Majenang yaitu pasien yang datang ke poli HIV akan dilakukan anamnesa terhadap pasien tersebut akan dilakukan konseling selanjutnya konselor akan menulis pada rekam medis. Lalu petugas akan membuat rekapan perbulanan Rekam medik HIV.

\footnotetext{
27 Informasi dari Dokter Penanggung Jawab Poli HIV.

28 Ibid.

29 Ibid.
} 
881 J u r n a I I d e a H u k u m

Vol 4 No, $1 \mathrm{M}$ a ret 2018

Magister H u k m F a k I tas H u k m U n i versitas

Jenderal Soedirman

Kemudian petugas cara online di sistim informasi HIV. Standar operasional prosedur pada pasien yang akan melakukan operasi akan dilakukan tes HIV pada bangsal ${ }^{30}$

Pasien yang dicurigai HIV di RSUD Majenang, dokter pemeriksa akan melaporkan kepada konselor, selanjutnya konselor akan mendatangi pasien tersebut dan mengedukasi untuk dilakukan tes HIV. Setelah dilakukan tes maka konselor akan menyampaikan hasil tes HIV, dengan cara hati-hati dan tertutup, untuk menjaga kerahasiaan pasien HIV. Setelah itu konselor juga akan memberikan edukasi secara rinci tentang HIV, cara penularan, cara minum obat, konselor juga akan memberikan edukasi ke pasien, konselor menawarkan kepada pasien perihal apakah hasil tes tersebut disampaikan ke orang terdekatnya. Standar operasional dengan pasien penderita TB diberikan edukasi untuk dilakukannnya tes HIV tidak lupa dengan penyampaian tersebut diperlukan informed concent.

Rekam medik pada pasien HIV akan dijaga kerahasiaannya oleh petugas kesehatan. Kerahasiaan rekam medik HIV dipastikan akan terjaga kerahasiaannya. Standar operasional dengan pasien penderita TB diberikan edukasi

30 Informasi dari Direktur RSUD Majenang. untuk dilakukannnya tes HIV tidak lupa dengan penyampaian tersebut diperlukan informed concent. Petugas rekam medik pasien HIV RSUD Majenang berbeda dengan petugas rekam medik pasien umum. Petugas rekam medik merupakan bagian dari tim konselor HIV. Petugas rekam medik HIV akan merekap pasien HIV tiap bulan kemudian akan melaporkan penderita HIV secara online pada sistim informasi HIV. Tim konselor termasuk petugas rekam medik setiap 3 bulan sekali akan mengikuti monitoring dan evaluasi TB HIV yang dilakukan oleh Dinas Kesehatan Kabupaten Cilacap maupun Dinas Kesehatan Propinsi. Sampai saat ini belum ada rekam medik yang dibuka kerahasiaannya untuk kepentingan keilmuan. Data pasien HIV akan dilaporkan secara online sesuai dengan prosedur yang ada. Data rekam medik pasien HIV hanya di laporkan kepada kepala bidang pelayanan tanpa menyebutkan identitas pasien, yang dilaporkan hanya jumlah penderita HIV tiap 3 bulan. ${ }^{31}$

Pembukaan rahasia kedokteran dalam Permenkes RI No. 269/MENKES/PER/III/2008 BAB IV pada Pasal 10 ayat (2) dijelaskan bahwa informasi tentang identitas, diagnosa, riwayat penyakit, riwayat pemeriksaan, dan riwayat pengobatan dapat dibuka dalam hal:

${ }^{31}$ Ibid 


\begin{abstract}
untuk kepentingan kesehatan pasien, Memenuhi permintaan aparatur penegak hukum dalam rangka penegakan hukum atas perintah pengadilan, permintaan dan atau persetujuan pasien sendiri, permintaan institusi/lembaga berdasarkan ketentuan perundangundangan, dan untuk kepentingan penelitian, pendidikan dan audit medis sepanjang tidak menyebutkan identitas pasien. Selanjutnya pada ayat (3) Permenkes nomer 269 tahun 2008 disebutkan bahwa permintaan rekam medis untuk tujuan sebagaimana dimaksud pada ayat (2) harus dilakukan secara tertulis kepada pimpinan sarana pelayanan kesehatan.
\end{abstract}

Semua informasi pasien apapun penyakitnya, yang berdasarkan undang-undang tidak boleh diberikan pada pihak yang tidak berkepentingan. Rahasia kedokteran merupakan data dan informasi tentang kesehatan seseorang yang diperoleh tenaga kesehatan pada waktu menjalankan pekerjaan atau profesinya. Sesuai kode etik kedokteran, setiap dokter wajib merahasiakan segala sesuatu yang diketahui tentang seorang penderita, bahkan juga setelah penderita itu meninggal dunia. Pasal 48 ayat (1) UU Nomor 29 Tahun 2004 tentang Praktik Kedokteran menyatakan setiap dokter atau dokter gigi dalam melaksanakan praktik kedokteran wajib menyimpan rahasia kedokteran. Saat ini telah ada peraturan yang mengatur rahasia kedokteran yaitu Peraturan Menteri Kesehatan Nomor 36 Tahun 2012 tentang Rahasia Kedokteran.

Rahasia kedokteran menurut Peraturan Menteri Kesehatan Nomor 36 Tahun 2012 tentang Rahasia Kedokteran mencakup tentang identitas pasien, kesehatan pasien meliputi hasil anamnesis, pemeriksaan fisik, pemeriksaan penunjang, penegakan diagnosis, pengobatan dan/atau tindakan kedokteran; dan hal lain yang berkenaan dengan pasien. Selain dokter, rumah sakit juga memiliki kewajiban untuk menjaga rahasia kedokteran. Setiap rumah sakit harus menyimpan rahasia kedokteran.

Kewajiban menyimpan rahasia kedokteran diatur dalam Pasal 4 Peraturan Menteri Kesehatan Nomor 36 Tahun 2012 tentang Rahasia Kedokteran, sebagai berikut: Semua pihak yang terlibat dalam pelayanan kedokteran dan atau menggunakan data dan informasi tentang pasien wajib menyimpan rahasia kedokteran; Pihak sebagaimana dimaksud pada ayat (1) meliputi: dokter dan dokter gigi serta tenaga kesehatan lain yang memiliki akses terhadap data dan inormasi kesehatan pasien, pimpinan fasilitas pelayanan kesehatan, tenaga yang berkaitan dengan pembiayaan pelayanan kesehatan, tenaga lainnya yang memiliki akses terhadap data dan 
883 | J u rna I I d e a H u k u m

Vol, $4 \mathrm{No}, 1 \mathrm{Maret} 2018$

Magister H u k u $\mathrm{F}$ a kultas H u k u $\mathrm{m}$ n i versitas

Jenderal Soedirman

\begin{abstract}
informasi kesehatan pasien di fasilitas pelayanan kesehatan, badan hukum/korporasi dan atau fasilitas pelayanan kesehatan, mahasiswa/siswa yang bertugas dalam pemeriksaan, pengobatan, perawatan dan atau manajemenin informasi di fasilitas pelayanan kesehatan; Kewajiban menyimpan rahasia kedokteran berlaku selamanya walaupun pasien telah meninggal dunia.
\end{abstract}

Peraturan Menteri Kesehatan Nomor 36 Tahun 2012 tentang Rahasia Kedokteran juga mengatur tentang pembukaan rekam medik yang tercantum dalam Pasal 5 sebagai berikut: Rahasia kedokteran dapat dibuka hanya untuk kepentingan kesehatan pasien, memenuhi permintaan aparatur penegak hukum dalam rangka penegakan hukum, permintaan pasien sendiri atau berdasarkan ketentuan peraturan perundangundangan; Pembukaan rahasia kedokteran sebagaimana dimaksud pada ayat (1) dilakukan terbatas sesuai kebutuhan.

Selanjutnya pada Pasal 6 Peraturan Menteri Kesehatan Nomor 36 Tahun 2012 tentang Rahasia Kedokteran memberikan penjelasan lebih lanjut ketentuan yang diatur dalam Pasal 5 sebagai berikut: Pembukaan rahasia kedokteran untuk kepentingan kesehatan pasien sebagaimana dimaksud dalam Pasal 5 meliputi: Kepentingan pemeliharaan kesehatan, pengobatan, penyembuhan dan perawatan pasien dan Keperluan administrasi, pembayaran asuransi atau jaminan pembiayaan kesehatan; Pembukaan rahasia kedokteran sebagaimana dimaksud pada ayat (1) huruf a dilakukan dengan persetujuan dari pasien; Pembukaan rahasia kedokteran sebagaimana dimaksud pada ayat (1) huruf b dilakukan dengan persetujuan dari pasien baik secara tertulis maupun sistem informasi elektronik; Persetujuan dari pasien sebagaimana dimaksu\& pada ayat (3) dinyatakan telah diberikan pada saat pendaftaran pasien di fasilitas pelayanan kesehatan; Dalam hal pasien tidak cakap untuk memberikan persetujuan sebagaimana dimaksud pada ayat (2), persetujuan dapat diberikan oleh keluarga terdekat atau pengampunya.

Pengaturan pembukaan rekam medik terkait dengan permintaan aparatur penegak hukum untuk kepentingan pengadilan diatur dalam Pasal 7 Permenkes nomer 36 tahun 2012 sebagai berikut: Pembukaan rahasia kedokteran untuk memenuhi permintaan aparatur penegak hukum dalam rangka penegakan hukum sebagaimana dimaksud dalam Pasal 5 dapat dilakukan pada proses penyelidikan, penyidikan, penuntutan dan sidang pengadilan; Pembukaan rahasia kedokteran sebagaimana dimaksud pada ayat 
(1) dapat melalui pemberian data dan informasi berupa visum et repertum, keterangan ahli, keterangan saksi dan atau ringkasan medis; Permohonan untuk pembukaan rahasia kedokteran sebagaimana dimaksud pada ayat (1) harus dilakukan secara tertulis dari pihak yang berwenang; Dalam hal pembukaan rahasia kedokteran dilakukan atas dasar perintah pengadilan atau dalam sidang pengadilan maka rekam medis seluruhnya dapat diberikan.

Pengaturan pembukaan
rekam medik atas permintaan
pasien sendiri diatur dalam Pasal 8
Peraturan Menteri Kesehatan Nomor
36 Tahun 2012 tentang Rahasia
Kedokteran sebagai berikut:
Pembukaan rahasia kedokteran atas
dasar permintaan pasien sendiri
sebagaimana dimaksud dalam Pasal
5 dapat dilakukan dengan
pemberian data dan informasi
kepada pasien baik secara lisan
maupun tertulis; Keluarga terdekat
pasien dapat memperoleh data dan
informasi kesehatan pasien kecuali
dinyatakan sebaliknya oleh pasien;
Pernyataan pasien sebagaimana
dimaksud pada ayat (2) diberikan
pada waktu penerimaan pasien.

Pengaturan pembukaan rekam medik berdasarkan ketentuan peraturan perundang-undangan diatur dalam Pasal 9 Permenkes nomer 36 tahun 2012 sebagai berikut: Pembukaan rahasia kedokteran berdasarkan ketentuan peraturan perundang-undangan sebagaimana dimaksud dalam Pasal 5 dilakukan tanpa persetujuan pasien dalam rangka kepentingan penegakan etika atau disiplin serta kepentingan umum; Pembukaan rahasia kedokteran dalam rangka kepentingan penegakan etik atau disiplin sebagaimana dimaksud pada ayat (1) diberikan atas permintaan tertulis dari Majelis Kehormatan Etik Profesi atau Majelis Kehormatan Disiplin Kedokteran Indonesia; Pembukaan rahasia kedokteran dalam rangka kepentingan umum sebagaimana dimaksud pada ayat (1) dilakukan tanpa membuka identitas pasien; Kepentingan umum sebagaimana dimaksud pada ayat (1) meliputi: audit medis, ancaman Kejadian Luar Biasa/wabah penyakit menular, penelitian kesehatan untuk kepentingan negara, pendidikan atau penggunaan informasi yang akan berguna di masa yang akan datang, dan ancaman keselamatan orang lain secara individual atau masyarakat.

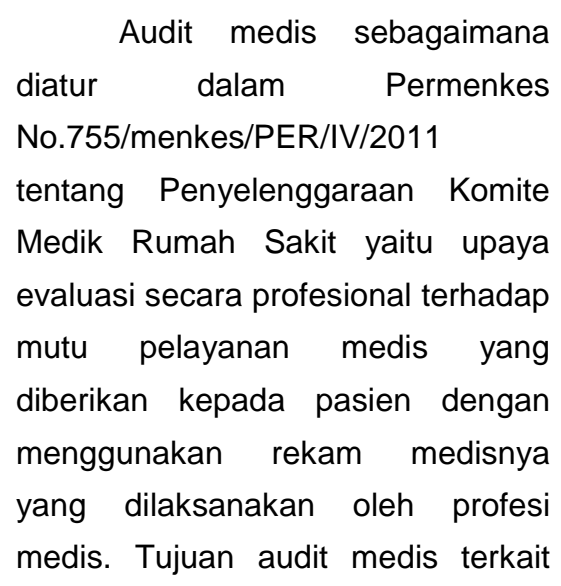


885 | J u rna I I d e a H u k u m

$\mathrm{Vol}, 4 \mathrm{No}, 1 \mathrm{Maret} 2018$

Magister H u k u $\mathrm{F}$ a kultas H u k u $\mathrm{m}$ n i versitas

Jenderal Soedirman

dengan upaya peningkatan mutu dan standarisasi, adalah tercapainya pelayanan prima di rumah sakit. Pelaksanaan audit medis dilaksanakan sebagai implementasi fungsi manajemen klinis dalam rangka penerapan tata kelola klinis yang baik di rumah sakit.

Wabah Penyakit Menular adalah kejadian berjangkitnya suatu penyakit menular dalam masyarakat yang jumlah penderitanya meningkat secara nyata melebihi daripada keadaan yang lazim pada waktu dan daerah tertentu serta dapat menimbulkan malapetaka. Kejadian Luar Biasa adalah timbulnya atau meningkatnya kejadian kesakitan/kematian yang bermakna secara epidemiologis pada suatu daerah dalam kurun waktu tertentu, dan merupakan keadaan yang dapat menjurus pada terjadinya wabah.

Pasal 1 Peraturan

Pemerintah Republik Indonesia Nomor 39 Tahun 1995 Tentang Penelitian Dan Pengembangan Kesehatan menegaskan bahwa penelitian dan pengembangan kesehatan adalah kegiatan ilmiah yang dilakukan menurut metode yang sistematik untuk menemukan informasi ilmiah dan/atau teknologi yang baru, membuktikan kebenaran atau ketidakbenaran hipotesis sehingga dapat dirumuskan teori atau suatu proses gejala alam dan/atau sosial di bidang kesehatan, dan dilanjutkan dengan menguji penerapannya untuk tujuan praktis di bidang kesehatan Penyelenggara peneliti dan pengembangan kesehatan adalah setiap peneliti, lembaga atau badan hukum baik milik Negara maupun swasta, yang menyelenggarakan penelitian dan pengembangan kesehatan. Peneliti adalah setiap orang yang bertugas melakukan penelitian dan pengembangan kesehatan. Penerapan hasil penelitian dan pengembangan kesehatan adalah setiap kegiatan untuk memanfaatkan atau menggunakan hasil penelitian dan pengembangan kesehatan bagi kepentingan praktis.

Kerahasiaan pembukaan rekam medik pasien HIV/AIDS tentu saja harus dikaitkan dengan upaya penanggulangan HIV/AIDS sehingga dapat mencegah rantai penularan HIV/AIDS. Penularan HIV/AIDS dalam rumah tangga dari istri ke suami atau suami ke istri harus mendapatkan perhatian yang lebih karena dapat berdampak pada anak yang dilahirkan. Oleh karena itu, sudah sewajarnyalah jika suami terkena HIV/AIDS, maka istri perlu diberitahu sehingga dapat tetap menjalankan kehidupan rumah tangga dengan tetap menjaga risiko terjadinya penularan HIV/AID dalam keluarga. Perlindungan dokter dalam konteks pembukaan rekam medik di rumah tangga yaitu pada istri atau suami ini merujuk pada ketentuan Pasal 9 Peraturan Menteri Kesehatan Nomor 36 Tahun 2012 tentang Rahasia Kedokteran ayat (4) 
huruf e yaitu ancaman keselamatan orang lain secara individual atau masyarakat.

Pembukaan rekam medik oleh penanggung jawab pelayanan pasien diatur dalam Pasal 10 Permenkes nomer 36 tahun 2012 sebagai berikut: pembukaan atau pengungkaan rahasia kedokteran dilakukan oleh penanggung jawab pelayanan pasien; Dalam hal pasien ditangani/dirawat oleh tim maka ketua tim yang berwenang membuka rahasia kedokteran; Dalam hal ketua tim sebagaimana dimaksud pada ayat (2) berhalangan maka pembukaan rahasia kedokteran dapat dilakukan oleh salah satu anggota tim yang ditunjuk; dan Dalam hal penanggung jawab pelayanan pasien tidak ada maka pimpinan fasilitas pelayanan kesehatan dapat membuka rahasia kedokteran.

Penanggung jawab pelayanan pasien atau pimpinan fasilitas pelayanan kesehatan dapat menolak membuka rahasia kedokteran apabila permintaan tersebut bertentangan dengan ketentuan peraturan perundangundangan. Pembukaan rahasia kedokteran harus didasarkan pada data dan informasi yang benar dan dapat dipertanggung jawabkan (Pasal 11 dan 12).

Rekam medik sudah tidak menjadi kerahasian kedokteran jika pasien melakukan tuntutan terhadap tenaga kesehatan dan telah menginformasikan melalui media massa. Hal ini diatur dalam Pasal 13 Permenkes nomer 36 tahun 2012 sebagai berikut: Pasien atau keluarga terdekat pasien yang telah meninggal dunia yang menuntut tenaga kesehatan dan/atau ; asilitas pelayanan kesehatan serta menginformasikannya melalui media massa diangga, telah melepaskan hak rahasia kedokterannya kepada umum; Penginformasian melalui media massa sebagaimana dimaksud pada ayat (1) memberikan kewenangan kepada tenaga kesehatan dan/atau fasillitas pelayanan kesehatan untuk membuka atau mengungkan rahasia kedokteran yang bersangkutan sebagai hak jawab.

Dalam hal pihak pasien menggugat tenaga kesehatan dan/atau fasilitas pelayanan kesehatan maka tenaga kesehatan dan/atau fasilitas pelayanan kesehatan yang digugat berhak membuka rahasia kedokteran dalam rangka pembelaannya di dalam sidang pengadilan (Pasal 14 Permenkes nomer 36 tahun 2012). Ketentuan yang mengatur kerahasiaan rekam medik pasien tidak dibedakan berdasarkan jenis penyakit pasien.

\section{Perlindungan Hukum Dokter Dalam Membuka Rekam Medis Pada Pasien HIV/AIDS}

Menurut Pasal 1 Anggaran 
Vol. $4 \mathrm{No}, 1 \mathrm{Maret} 2018$

Ma gister H u k m F a k I tas H u k u U n i versitas

J e nderal soedirm a n

Dasar Perhimpunan Hukum

Kesehatan Indonesia (Perhuki), hukum kesehatan adalah semua ketentuan hukum yang berhubungan langsung dengan pemeliharaan/pelayanan kesehatan dan penerapannya serta hak dan kewajiban baik dari perorangan dan segenap lapisan masyarakat sebagai penerima layanan kesehatan maupun dalam segala aspek organisasi, sarana, pedomanpedoman medis nasional/internasional, hukum dibidang kesehatan, jurisprudensi serta ilmu pengetahuan bidang kedokteran/kesehatan. ${ }^{32}$ Undang-Undang No 29 Tahun 2004 tentang Praktik Kedokteran diundangkan untuk mengatur praktik kedokteran. Peraturan ini bertujuan agar dapat memberikan perlindungan kepada pasien, mempertahankan dan meningkatkan mutu pelayanan medis dan memberikan kepastian hukum kepada masyarakat, dokter dan dokter gigi.1 Pada bagian awal, Undang-Undang No. 29 Tahun 2004 mengatur tentang persyaratan dokter untuk dapat berpraktik kedokteran, yang dimulai dengan keharusan memiliki sertifikat kompetensi kedokteran yang

32 Hendrik, 2012. Etika dan Hukum Kesehatan, Jakarta : Penerbit Buku Kedokteran, hlm. 24-25. diperoleh dari Kolegium selain ijazah dokter yang telah dimilikinya, keharusan memperoleh Surat Tanda Registrasi dari Konsil Kedokteran Indonesia dan kemudian memperoleh Surat ijin Praktik dari Dinas Kesehatan Kota atau Kabupaten. Dokter tersebut juga harus telah mengucapkan sumpah dokter, sehat fisik dan mental serta menyatakan akan mematuhi dan melaksanakan ketentuan etika profesi. 33 Peraturan dan perundangan yang berkaitan dengan hukum kesehatan, antara lain: KUHPerdata dan KUHPidana; Undang-Undang No. 29 tahun 2004 Tentang Praktik Kedokteran; Undang-Undang No. 36 tahun 2009 Tentang Kesehatan; UndangUndang Nomor 44 Tahun 2009 Tentang Rumah Sakit; Peraturan Pemerintah No, 10 tahun 1966 Tentang Wajib Simpan Rahasia Kedokteran; Peraturan Menteri Kesehatan No. 512/Menkes/Per/IV/2007 Tentang Izin Praktek dan Pelaksanaan Praktek Kedokteran; Peraturan Menteri Kesehatan No.290/Menkes/Per/III/2008 Tentang Persetujuan Tindakan Kedokteran; Peraturan Menteri

\footnotetext{
${ }^{33}$ Budi Sampurna, Praktik Kedokteran Yang Baik Mencegah Malpraktik Kedokteran, Majalah Farmacia, Edisi: Maret 2006, hlm. 74
} 
Kesehatan

No.749a/Menkes/Per/XII/1989

\begin{tabular}{lcr} 
Tentang & Rekam & \multicolumn{2}{c}{ Medik/Medikal } \\
Record; & Keputusan & Konsil \\
Kedokteran & Indonesia & No. \\
17/KKI/Kep/VIII/2006 & Tentang \\
Penegakan & Disiplin & Profesi \\
Kedokteran; & Peraturan & Konsil \\
Kedokteran & Indonesia & No.15/ \\
KKI/Per/VIII/ & 2006 & Tentang
\end{tabular}

Organisai dan Tata organisasi dan

Tata Kerja Majelis Kehormatan

Disiplin Kedoteran Indonesia di

Tingkat Provinsi; Peraturan Konsil

Kedokteran Indonesia No.

16/KKI/Per/VIII/2006 Tentang Tata

Cara Penanganan Kasus Dugaan

Pelanggaran Disiplin Dokter dan

Dokter Gigi Oleh Majelis

Kehormatan Disiplin Kedokteran Indonesia Di Tingkat Provinsi;

Peraturan Konsil Kedokteran Indonesia No. 42/ KKI/Per/XII/2007

Tentang Tata Cara Registrasi Ulang,

Registrasi Sementara dan Registrasi

Bersyarat Dokter dan Dokter Gigi;

Peraturan Menteri Kesehatan

Republik Indonesia Nomor 269

Tahun 2008 tentang Rekam Medik;

Peraturan Menteri Kesehatan

Republik Indonesia Nomor 1438

Tahun 2010 Tentang Standar

Pelayanan Kedokteran; Peraturan

Menteri Kesehatan Nomor 36 Tahun

2012 tentang Rahasia Kedokteran;

Peraturan Menteri Kesehatan

Republik Indonesia Nomor 21 Tahun
2013 Tentang Penanggulangan HIV dan AIDS.

Keterikatan dokter terhadap ketentuan-ketentuan hukum dalam menjalankan profesinya merupakan tanggungjawab yang harus dipenuhi dokter, yaitu: ${ }^{34}$ Bidang administrasi, yang mana hal ini terdapat dalam Pasal 29, Pasal 30 dan Pasal 36 dan Pasal 37 Undang-undang Nomor 29 Tahun 2004 tentang Praktik Kedokteran; Bidang pidana, dimana perumusan pasal-pasal mengenai tanggungjawab praktik kedokteran tercantum dalam Pasal 75 sampai dengan Pasal 80, Undang-undang. Nomor 29 Tahun 2004 tentang Praktik Kedokteran; Bidang perdata, dalam hukum perdata, pertanggungjawaban dapat diklasifikasikan menjadi pertanggungjawaban karena perbuatan melanggar hukum sesuai dalam ketentuan Pasal $1365 \mathrm{KUH}$ Perdata dan pertanggungjawaban karena wanprestasi sesuai Pasal 1243 KUH Perdata. ${ }^{35}$

Sesuai dengan ketentuan dalam Pasal 44 ayat (3) UU No 29 Tahun 2004 Tentang Praktik Kedokteran, pemerintah melalui Menteri Kesehatan menerbitkan Peraturan Menteri Kesehatan No 1438 Tahun 2010 Tentang Standar Pelayanan Kedokteran. Dalam peraturan ini dijelaskan bahwa standar pelayanan kedokteran terdiri

34 Nusye Jayanti, 2009, Op. Cit, hlm. 24

35 Triwulan Tutik, Op. Cit., hlm..49-50 
889 | Ju rna I I d e a H u k u m

$\mathrm{Vol}, 4 \mathrm{No}, 1 \mathrm{Maret} 2018$

Magister Hu ku $\mathrm{FakuItas} H$ u k u m U i versitas

Jenderal Soedirman

dari dua ketentuan: pedoman nasional pelayanan kedokteran dan standar prosedur operasional. Keduanya adalah pedoman bagi dokter dan tenaga medis untuk menjalankan tindakan medis. Standar pelayanan kedokteran sebagai pedoman yang harus diikuti oleh dokter dalam menyelenggarakan praktik kedokteran. Pedoman nasional pelayanan kedokteran merupakan standar pelayanan kedokteran yang bersifat nasional yang dibuat oleh organisasi profesi dan disahkan oleh menteri. Standar prosedur operasional merupakan suatu perangkat instruksi/langkah-langkah yang dibakukan untuk menyelesaikan proses kerja rutin tertentu, atau langkah yang benar dan terbaik berdasarkan konsensus bersama dalam melaksanakan berbagai kegiatan dan fungsi pelayanan dapat bekerja dengan aman.

Menurut konselor dan
penanggung jawab poli HIV
merupakan dilema atas Permenkes
nomer 269 tahun 2008 tersebut
karena tidak boleh dibuka rekam
medik tanpa seijin pasien. Hal ini
bisa menjadi penyebab terjadinya
peningkatan penderita HIV
khususnya di Kabupaten Cilacap,
akibat tidak dapat dipantaunya
aktivitas seksual dengan penderita
HIV. Pada permenkes
penanggulangan HIV tenaga
kesehatan wajib memberikan

pelayanan penanggulangan HIV secara komperenhensif baik itu promotif, preventif, kuratif, dan rehabilitatif. Selain itu tugas tenaga kesehatan dalam kode etiknya tidak boleh membuka rahasia pasien. Walaupun pasien tersebut meninggal, hal ini sampai ditiadakannya penderita HIV baru. ${ }^{36}$ Adanya ketentuan yang diatur dalam Permenkes RI No. 269/MENKES/PER/III/2008 BAB IV pada Pasal 10 ayat (2) dan Pasal 4 sampai dengan Pasal 14 Peraturan Menteri Kesehatan Nomor 36 Tahun 2012 tentang Rahasia Kedokteran menjadi rambu-rambu yang jelas bagi dokter dalam membuka rekam medik, khususnya rekam medik pasien HIV/AIDS. Selama alasan atau pertimbangan yang dilakukan oleh dokter dalam membuka rekam medik sesuai dengan ketentuan yang diatur dalam peraturan perundang-undangan tersebut, maka dokter akan terlindungi seara hukum terhadap tindakannya dalam membuka rekam medik pasien HIV/AIDS.

Norma hukum yang tercantum dalam Undang-Undang Nomor 29 Tahun 2004 Tentang Praktek Kedokteran merupakan norma hukum administrasi. Namun dalam undang-undang ini juga tercantum ketentuan pidana di dalam Pasal 75 sampai dengan 80 .

36 Informasi dari Dokter Penanggung Jawab Poli HIV. 
Pencantuman sanksi pidana dalam undang-undang tidak lepas dan fungsi hukum pidana secara umum yaitu ultimum remedium, merupakan salah satu asas yang terdapat di dalam hukum pidana Indonesia yang mengatakan bahwa hukum pidana hendaklah dijadikan upaya terakhir dalam hal penegakan hukum. Hal ini memiliki makna apabila suatu perkara dapat diselesaikan melalui jalur lain (perdata dan hukum administrasi) hendaklah jalur tersebut dilalui terlebih dahulu. Pencantuman sanksi pidana dalam undang-undang praktek kedokteran, pada pelanggaran norma hukum administrasi tertentu berarti pembuat undang-undang menilai sanksi administrasi saja tidak cukup, sehingga diperlukan sanksi pidana.

Sejalan dengan Pasal 1 ayat (3) Undang-undang Dasar Negara Republik Indonesia Tahun 1945 yang secara tegas menyatakan bahwa Negara Indonesia adalah Negara Hukum. Dengan demikian pembangunan nasional dibidang hukum ditujukan agar masyarakat memperoleh kepastian, ketertiban dan perlindungan hukum yang berintikan kebenaran dan keadilan serta memberikan rasa aman dan tentram. Perlindungan hukum dokter dalam pembukaan rekam medik diantaranya agat secara fisik dan psikis para dokter dilindungi dalam menjalankan tugas dan fungsinya sehingga dapat menjalankan fungsinya secara optimal dan akan mencegah atau menekan sekecil mungkin adanya kesalahan atau ketidaksengajaan yang membuat terjadinya pelanggaran (malpraktik) ataupun pelanggaran disiplin.

Dokter akan terlindungi secara hukum dalam membuka rekam medik pasien HIV/AIDS jika pembukaan rekam medik tersebut dilakukan sesuai dengan kewenangan yang diatur dalam Pasal 9 Peraturan Menteri Kesehatan Nomor 36 Tahun 2012 tentang Rahasia Kedokteran sebagai berikut: Pembukaan rahasia kedokteran berdasarkan ketentuan peraturan perundang-undangan sebagaimana dimaksud dalam Pasal 5 dilakukan tanpa persetujuan pasien dalam rangka kepentingan penegakan etika atau disiplin serta kepentingan umum; Pembukaan rahasia kedokteran dalam rangka kepentingan penegakan etik atau disiplin sebagaimana dimaksud pada ayat (1) diberikan atas permintaan tertulis dari Majelis Kehormatan Etik Profesi atau Majelis Kehormatan Disiplin Kedokteran Indonesia; Pembukaan rahasia kedokteran dalam rangka kepentingan umum sebagaimana dimaksud pada ayat (1) dilakukan tanpa membuka identitas pasien; Kepentingan umum sebagaimana dimaksud pada ayat (1) meliputi: audit medis, ancaman Kejadian Luar Biasa/wabah penyakit menular, penelitian kesehatan untuk kepentingan negara, pendidikan 
891 | J u rna I I d e a H u k u m

Vol, $4 \mathrm{No}, 1 \mathrm{M}$ a ret 2018

Magister H u k u $\mathrm{F}$ a kultas H u k u $\mathrm{m}$ n i versitas

Jenderal Soedirman

atau penggunaan informasi yang akan berguna di masa yang akan datang, dan ancaman keselamatan orang lain secara individual atau masyarakat.

Ketentuan yang diatur dalam

Pasal 9 Peraturan Menteri Kesehatan Nomor 36 Tahun 2012 tentang Rahasia Kedokteran memberikan perlindungan hukum bagi dokter dalam membuka rekam medik pasien HIV/AIDS. Pembukaan rekam medik pasien HIV/AIDS oleh dokter selama memenuhi kriteria yang diatur dalam peraturan tersebut maka dokter akan terlindungi secara hukum.

\section{SIMPULAN DAN SARAN}

Simpulan

Kewenangan dokter dalam membuka rekam medik pasien HIV/AIDS diatur dalam Permenkes RI nomer 269/MENKES/PER/III/2008 dan nomer 36 tahun 2012 tentang Rahasia Kedokteran yaitu hanya untuk untuk kepentingan kesehatan pasien, memenuhi permintaan aparatur penegak hukum dalam rangka penegakan hukum atas perintah pengadilan yang harus dimintakan secara tertulis kepada pimpinan sarana pelayanan kesehatan, permintaan dan atau persetujuan pasien sendiri, permintaan institusi/lembaga berdasarkan ketentuan perundangundangan serta untuk kepentingan

$$
\begin{aligned}
& \text { penelitian, pendidikan dan audit } \\
& \text { medis sepanjang tidak } \\
& \text { menyebutkan identitas pasien, } \\
& \text { serta suatu kondisi yang } \\
& \text { mengancam keselamatan orang } \\
& \text { lain secara individu maupun } \\
& \text { masyarakat. Individu yang } \\
& \text { dimaksud adalah orang yang paling } \\
& \text { berpotensi tertularnya HIV/AIDS } \\
& \text { yaitu istri atau suami penderita } \\
& \text { HIV/AIDS. } \\
& \text { Perlindungan hukum dalam } \\
& \text { membuka rekam medis pada } \\
& \text { pasien HIV/AIDS diberikan oleh } \\
& \text { pemerintah secara preventif } \\
& \text { bertujuan untuk mencegah } \\
& \text { terjadinya sengketa, yang } \\
& \text { mengarahkan tindakan yang } \\
& \text { bersikap kehati-hatian dengan } \\
& \text { adanya berbagai ketentuan yang } \\
& \text { diatur dalam undang-undang } \\
& \text { praktik kedokteran, kesehatan dan } \\
& \text { peraturan menteri kesehatan. } \\
& \text { Perlindungan perlindungan hukum } \\
& \text { secara represif jika sudah terjadi } \\
& \text { pelanggaran dalam praktek } \\
& \text { pelayanan kedokteran yang } \\
& \text { bertujuan untuk penanganan suatu } \\
& \text { sengketa tertentu yang juga diatur } \\
& \text { dalam KUHP dan peraturan } \\
& \text { peundang-undangan untuk } \\
& \text { menjamin dokter dan pasien } \\
& \text { mendapatkan hak dan } \\
& \text { kewajibannya sesuai dengan } \\
& \text { ketentuan peraturan perundang- } \\
& \text { undangan yang berlaku. }
\end{aligned}
$$

\section{Saran}

1. Pasien HIV/AIDS perlu diberikan pemahaman tentang HIV/AIDS 


\begin{abstract}
secara komprehensif dan terbuka termasuk risiko penularan HIV/AIDS, dikandung maksud dapat meningkatkan psikologis penderita HIV/AIDS sehingga dapat hidup membaur dengan masyarakat tanpa merasa terkucilkan serta menurunkan angka penularan HIV/AIDS.
\end{abstract}

2. Data rekam medik penderita HIV/AIDS diperbolehkan dibuka untuk orang yang berpotensi tinggi tertular HIV/AIDS yaitu suami dari istri penderita HIV/AIDS atau istri dari suami penderita HIV/AIDS. Hal ini untuk mengurangi penyebaran HIV/AIDS

\section{DAFTAR PUSTAKA}

Admosudirjo, Prajudi. 1994 Hukum Administrasi Negara Jakarta: Ghalia Indonesia

Az.Nasution. 2011. Hukum Perlindungan Konsumen Suatu Pengantar. Jakarta: Diadit Media

Bhekti Suryani, 2013.Panduan Yuridis Penyelenggaraan Praktik Kedokteran, Jakarta, Dunia Cerdas

Christine S.T. Kansil, 1991, Pengantar Hukum Kesehatan Indonesia, Jakarta: Rineka Cipta

1997, Pokok-Pokok Etika Profesi Hukum, Jakarta: Pradnya Paramita

Daldiyono, 2007, Pasien Pintar dan Dokter Bijak, Jakarta: Buana IImu Popular

Danny Wiradharma, 2001, Etika Profesi Medik, Jakarta, Universitas Trisakti
Ery Rustiyanto, 2009, Etika Profesi Perekam Medik \& Informasi Kesehatan, Yogyakarta: Graha IImu

Hermien Hardiati Koeswadji, 1998, Hukum Kedokteran. Studi tentang Hubungan Hukum dalam Mana Dokter sebagai Salah Satu P ihak, Jakarta, Aditya Bakti

H.J.J. Leenen dan P.A.F. Lamintang. 1991. Pelayanan Kesehatan dan Hukum. Bandung : Binacipta

I.S. Susanto. 2003. Pembinaan Lembaga dan Pranata Hukum. Purwokerto : Program Pascasarjana Magister IImu Hukum.

Margarita M. Maramis, 2007, Konseling dan Tes Sukarela Untuk Penderita HIV \& AIDS, dalam Nasronudin \& Margarita M. Maramis (editor), Konseling, Dukungan, Perawatan \& Pengobatan ODHA, Airlangga University Press, Surabaya.

Maria Alfons, 2010. Implementasi Perlindungan Indikasi Geografis atas Produk-Produk Masyarakat Lokal dalam Prespektif Hak Kekayaan Intelektual. Malang: Universitas Brawijaya

M. Taufik. 2011. "Perspektif Yuridis Tanggung Jawab Dokter Terhadap Rahasia Medik Pasien HIV/AIDS (Studi di Rumah Sakit Umum Daerah Banyumas)" Jurnal Dinamika Hukum Vol. 11 No. 3 September 2011

Muhari Agus Santoso. 2002. Paradigma Baru Hukum Pidana, Averroes Press, Pustaka Pelajar Malang

Munir Fuadi, 2003. Aliran Hukum Kritis, Paradigma Ketidakberdayaan Hukum, Bandung. Citra Aditya Bakti

N.H.T Siahaan, 2009, Hukum Lingkungan, Jakarta: Pancuran Alam

Ninik Maryati, 1998, Malpraktik Kedokteran dari Segi Hukum Pidana dan Perdata,. Jakarta, Bina Aksara

Nusye K.I Jayanti, 2009.Penyelesaian Hukum Dalam Malperaktek 
893 | J u rn a I I d e a H u k u m

Vol, $4 \mathrm{No}, 1 \mathrm{M}$ are t 2018

Magister Hu k u $\mathrm{FakuItas} H$ u k u $\mathrm{m}$ U n iversitas

J endera I Soedirman

Kedokteran, Yogyakarta, Pustaka

Yustisia

Philipus M. Hadjon dkk, 1988, Hukum Administrasi Indonesia, Gadjah Mada University Press, Yogyakarta

---------. 1993. Pengantar Hukum Perizinan. Surabaya: Yuridika

Ridwan, HR, 2002, Hukum Administrasi Negara, UII Press, Yogyakarta

Rismalinda, 2011, Etika Profesi dan Hukum Kesehatan, Jakarta. Trans Info Media

Samsi Jacobalis, 2005, Pengantar Tentang Perkembangan IImu Kedokteran, Etika Medik, dan Bioetika, CV Sagung Seto bekerjasama dengan Universitas Tarumanegara, Jakarta.

Satjipto Rahardjo. 2000. IImu Hukum. Bandung: Citra Aditya Bakti

Soehino, 1985, IImu Negara, Yogyakarta. Liberty

Soenarko, 1998, Public Policy Pengertian Pokok untuk Memahami dan Analisa Kebijakan Pemerintah. Papyrus, Surabaya

Sutrisno, 1989. Pertanggungjawaban dokter dalam hukum Perdata, Varia Peradilan, IKAHI

Triwulan Tutik, T. 2010. Perlindungan Hukum Bagi Pasien Jakarta,..Prestasi Pustaka

Kode Etik Kedokteran Indonesia 